\title{
Penerapan Model Picture and Picture Dengan Media Audio Visual untuk Meningkatkan Kualitas Pembelajaran IPS
}

\author{
Novi Marselia \\ SDN 3 Kemiriombo \\ marselialia25@gmail.com
}

\section{Article History}

received 3/12/2020

\begin{abstract}
The research aimed to increase social subject quality of third grade elementary school students through the application of picture and picture model using audio visual. The research was designed using classroom action research consisted of planning, action, observation, and reflection. The data was collected using test, observation, documentation, and learning log. The result of teacher skill in the first cycle scored 25 in good category. Cycle II scored 26 in good category. Cycle III scored 33 in excelent category. The results of cognitive learning classical completeness in the first cycle was $61 \%$. The second cycle was $78 \%$. The third cycle was $87 \%$.The conclusion was the application of picture and picture model using audio visual improved the quality of learning including teacher skills and student learning outcomes.
\end{abstract}

Keywords: audio visual, picture and picture model, quality of education

\section{Abstrak}

Tujuan penelitian ini adalah meningkatkan kualitas pembelajaran IPS siswa kelas III dengan penerapan model picture and picture dengan media audio visual. Penelitian ini menggunakan Penelitian Tindakan Kelas yang terdiri atas 3 siklus dengan tahapan perencanaan, pelaksanaan, observasi, dan refleksi. Teknik pengumpulan data adalah tes, observasi, dokumentasi, dan catatan lapangan. Hasil penelitian keterampilan guru siklus I mendapatkan skor 25 dengan kategori baik, siklus II mendapat skor 26 dengan kategori baik, dan siklus III mendapatkan skor 33 dengan kategori sangat baik. Ketuntasan klasikal belajar kognitif siklus I adalah $61 \%$, siklus II adalah $78 \%$, dan siklus III adalah $87 \%$. Simpulan penelitian adalah penerapan model picture and picture dengan media audio visual dapat meningkatkan kualitas pembelakjaran IPS kelas III yang meliputi keterampilan guru dan hasil belajar siswa.

Kata kunci: audio visua, model picture and picture, kualitas pembelajaran

Social, Humanities, and Education Studies (SHEs): Conference Series https://jurnal.uns.ac.id/shes

p-ISSN 2620-9284 e-ISSN 2620-9292 


\section{PENDAHULUAN}

Undang-Undang Dasar 1945 Pasal 31 memberikan kebebasan kepada setiap warga negara Indonesia untuk memperoleh pendidikan. Didukung dengan adanya Undang-Undang No. Undang-Undang No. 20 Tahun 2003 Tentang Sistem Pendidikan Nasional. Dalam UU yang menyatakan bahwa Pendidikan merupakan kunci kemajuan, semakin baik kualitas pendidikan yang diselenggarakan oleh suatu masyarakat/bangsa, maka akan diikuti dengan semakin baiknya kualitas masyarakat/bangsa tersebut.

Berdasarkan Peraturan Menteri Pendidikan Nasional Nomor 41 Tahun 2007 tentang Standar Proses, proses pembelajaran pada setiap satuan pendidikan dasar dan menengah harus interaktif, inspiratif, menyenangkan, menantang, dan memotivasi peserta didik untuk berpartisipasi aktif, serta memberikan ruang yang cukup bagi prakarsa, kreativitas, dan kemandirian sesuai dengan bakat, minat, dan perkembangan fisik serta psikologis peserta didik. Sejalan dengan pendapat tersebut, dalam kurikulum 2013 dijelaskan bahwa pendidikan bertujuan untuk mempersiapkan insan Indonesia supaya memiliki kemampuan hidup sebagai pribadi dan warganegara yang beriman, produktif, kreatif, inovatif, dan afektif serta mampu berkontribusi pada kehidupan bermasyarakat, berbangsa, bernegara dan peradaban dunia.

Seyogyanya proses penanaman konsep mendapat perhatian guru dalam kegiatan pembelajaran IPS di kelas sehingga yang menjadi tujuan pelaksanaan pembelajaran IPS yaitu untuk mempersiapkan para peserta didik sebagai warga negara yang menguasai pengetahuan, keterampilan, sikap dan nilai, yang dapat digunakan sebagai kemampuan untuk memecahkan masalah pribadi atau masalah sosial serta kemampuan mengambil keputusan dan berpartisipasi dalam berbagai kegiatan kemasyarakatan agar menjadi warga negara yang baik dapat tercapai dan dilakukan secara aktif dan menyenangkan (Sapriya, 2012).

Namun pada kenyataannya, pembelajaran IPS di kelas III SDN 3 Kemiriombo belum sesuai dengan harapan. Berdasarkan hasil refleksi yang dilakukan oleh peneliti bersama tim kolarasi melalui observasi dan catatan lapangan, ditemukan beberapa masalah dalam pembelajaran IPS diantaranya guru belum menerapkan model pembelajaran inovatif dan kurang mengoptimalkan penggunaan media pembelajaran yang mendukung, melainkan lebih banyak menggunakan metode ceramah satu arah dalam menyampaikan materi pembelajaran. Dari hasil pengamatan, terlihat bahwa siswa kurang aktif dalam pembelajaran. Siswa beralih untuk melakukan kegiatan yang lain ketika guru menjelaskan, seperti berbicara dengan teman sebangku dan bermain sendiri yang menyebabkan ramai di kelas sehingga guru sesekali menegur mereka. Kondisi yang demikian menjadikan suasana pembelajaran kurang kondusif. Beberapa siswa juga ada yang terlihat malas-malasan saat mendengarkan penjelasan materi. Kemudian, guru memberikan kesempatan kepada siswa untuk menanyakan materi yang belum dipahami namun tidak ada satu pun siswa yang bertanya. Ketika mengerjakan tugas, beberapa siswa terlihat kebingungan dan berjalan ke bangku temannya yang lain, sehingga mengganggu siswa lain yang sedang mengarjakan. Halhal seperti itu tentunya mengakibatkan kurangnya efektivitas pembelajaran dan pencapaian hasil belajar IPS di kelas III.

Fakta lain di lapangan yang menunjukkan bahwa hasil belajar siswa pada mata pelajaran IPS kelas III SDN 3 Kemiriombo belum mencapai target yang diharapkan, yaitu belum seluruhnya mencapai Kriteria Ketuntasan Minimal (KKM). Terdapat 14 dari 23 siswa (61\%) yang memperoleh nilai di bawah KKM, yaitu 75 , pada mata pelajaran IPS. Jumlah siswa yang mengalami ketuntasan belajar ialah 9 dari 23 siswa (39\%). Nilai terendah ialah 64 dan nilai tertinggi yang diperoleh adalah 86. Gambaran data hasil belajar tersebut, menunjukkan bahwa proses pembelajaran IPS di SDN 3 Kemiriombo tidak berkualitas, sedangkan untuk mendapatkan hasil belajar yang optimal dibutuhkan pembelajaran yang berkualitas. 
Sebagai alternatif penyelesaian masalah tersebut, maka dalam pembelajaran diterapkan model picture and picture. Model pembelajaran Picture and Picture menurut Hamdani (2011:89) merupakan suatu model pembelajaran yang menggunakan gambar yang dipasangkan atau diurutkan menjadi urutan yang logis. Picture and Picture merupakan salah satu bentuk model pembelajaran kooperatif. Model pembelajaran ini mengandalkan gambar-gambar sebagai media dalam pembelajaran yang dapat ditampilkan baik dalam bentuk kartu atau dapat juga menggunakan sound slide, power point, maupun dalam bentuk soft ware lainnya.

Suprijono berpendapat Picture and Picture merupakan strategi pembelajaran yang menggunakan gambar sebagai media pembelajaran, dan gambar yang diberikan pada siswa harus diurutkan menjadi urutan yang logis. Gambar tersebut menjadi perangkat utama dalam pembelajaran. Untuk itu, sebelum proses pembeljaran berlangsung, guru harus sudah menyiapkan gambar-gambar yang akan digunakan. Gambar-gambar tersebut dapat ditampilkan dalam bentuk kartu berukuran besar, melalui bantuan Power Point atau software-software lainnya.

Berdasarkan pendapat Hamdani dan Suprijono, dapat disimpulkan bahwa model pembelajaran Picture and Picture adalah model pembelajaran menggunakan gambargambar yang disusun menjadi urutan yang logis. Dengan adanya gambar dalam pembelajaran IPS tersebut, akan membantu memudahkan siswa untuk memahami materi yang disampaikan serta membangun pengetahuan baru. Hal tersebut dikarenakan gambar-gambar yang digunakan akan membantu mengkonkretkan materi- mateeri IPS yang sebagian besar bersifat abstrak atau verbal, karena pada anak usia SD tahap perkembangan berada pada tahap operasional konkret dimana siswa belum mampu berpikir secara abstrak, sehingga siswa masih membutuhkan media yang membantu mengkonkretkan materi-materi yang cenderung bersifat verbal. Dengan penggunaan gambar dalam pembelajaran, juga dapat menumbuhkan minat dan ketertarikan siswa terhadap materi yang disampaikan karena siswa usia SD masih cenderung menyukai penyajian materi yang lebih banyak meggunakan gambar dengan beberapa keterangan penjelas gambar tersebut. Dengan demikian siswa akan lebih mudah mengingat materi yang disampaikan melalui perantara gambar-gambar tersebut.

Media yang digunakan adalah audio visual, sehingga siswa akan termotivasi untuk aktif dalam pembelajaran IPS, sehingga pembelajaran akan menyenangkan dan lebih efektif.. Media audio visual merupakan gabungan dari dua tipe media yaitu audio dan visual (Daryanto, 2010: 16).

Media Audio-Visual adalah media yang mempunyai unsur suara dan unsur gambar. Jenis Media ini mempunyai kemampuan yang lebih baik, karena meliputi kedua jenis media yaitu Media Audio dan Media Visual. Dale mengemukakan bahwa bahan-bahan Audio-Visual dapat memberikan banyak manfaat asalkan guru berperan aktif dalam proses pembelajaran. Menurut seorang ahli komunikasi dan media pendidikan Rudy Breatz media pendidikan mempunyai ciri utama dan memiliki 3 unsur pokok yaitu suara, Visual dan gerak. Teknologi yang paling tua yang dimanfaatkan dalam proses belajar adalah percetakan yang bekerja atas dasar prinsip mekanis, kemudian lahir teknologi Audio-Visual yang menggabungkan penemuan mekanis dan elektronis untuk tujuan pembelajaran.

Sebagai media pembelajaran dalam pendidikan dan pengajaran, media audiovisual mempunyai sifat, yaitu (1) kemampuan untuk meningkatkan persepsi, (2) kemampuan untuk meningkatkan kemampuan, (3) kemampuan untuk meningkatkan transfer (pengalihan belajar), (4) kemampuan untuk memberikan penguatan atau pengetahuan hasil yang dicapai, dan (5) kemampuan untuk meningkatkan retensi (ingatan). 
Tujuan penelitian ini adalah untuk meningkatkan kualitas pembelajaran IPS siswa kelas III SDN 3 Kemiriombo Kecamatan Kaliwiro melalui penerapan model picture and picture dengan media audio visual.

\section{METODE}

Penelitian yang dilakukan adalah Penelitian Tindakan Kelas (PTK) yang meliputi tahap perencanaan, pelaksanaan, observasi, dan refleksi. (Arikunto, 2006), terdiri atas 3 siklus dengan 1 kali pertemuan pada setiap siklus yang dilaksanakan pada tanggal 18 Januari sampai 8 Februari 2020. Subyek penelitian adalah guru dan 23 siswa kelas III SDN 3 Kemiriombo Kecamatan Kaliwiro.

Teknik pengumpulan data menggunakan tektik non tes dan teknik tes. Jenis data meliputi data kualitatif dan data kuantitatif. Data kualitatif dianalisis menggunakan deskriptif kualitatif dan data kuantitatif dianalisis menggunakan analisis deskriptif dengan menentukan mean atau rerata, skor maksimal, skor minimal.

1. Keterampilan Guru

\section{HASIL DAN PEMBAHASAN}

Hasil penelitian yang menunjukkan peningkatan keterampilan guru dapat dilihat pada tabel berikut :

Tabel 1. Peningkatan Keterampilan Guru

\begin{tabular}{|c|c|c|c|c|}
\hline \multirow[b]{2}{*}{ No } & \multirow[b]{2}{*}{ Indikator } & \multicolumn{3}{|c|}{ Skor yang diperoleh } \\
\hline & & Siklus I & $\underset{\text { SI }}{\substack{\text { Siklus }\\
}}$ & $\underset{\text { SIII }}{\text { Siklus }}$ \\
\hline 1. & $\begin{array}{l}\text { Mempersiapkan siswa mengikuti pembelajaran IPS } \\
\text { KD 2.1 Mengenal jenis-jenis pekerjaan }\end{array}$ & 4 & 3 & 3 \\
\hline 2. & Melakukan kegiatan pendahuluan & 3 & 2 & 3 \\
\hline 3. & $\begin{array}{l}\text { Menyampaikan materi IPS KD } 2.1 \text { Mengenal jenis- } \\
\text { jenis pekerjaan secara umum }\end{array}$ & 3 & 2 & 4 \\
\hline 4. & Memilih dan menggunakan media audio visual & 2 & 3 & 4 \\
\hline 5. & $\begin{array}{l}\text { Menunjukkan gambar-gambar menggunakan } \\
\text { media audio visual }\end{array}$ & 3 & 3 & 4 \\
\hline 6. & Membagi kelas menjadi beberapa kelompok & 2 & 3 & 3 \\
\hline 7. & Membimbing diskusi kelompok & 2 & 3 & 4 \\
\hline 8. & $\begin{array}{l}\text { Mengkonfirmasi presentasi laporan kelompok } \\
\text { Memberikan penguatan materi IPS KD } 2.1\end{array}$ & 2 & 2 & 2 \\
\hline 9. & $\begin{array}{l}\text { Mengenal jenis-jenis pekerjaan dan motivasi } \\
\text { kepada siswa }\end{array}$ & 2 & 3 & 3 \\
\hline 10 & $\begin{array}{c}\text { Melakukan kegiatan penutup } \\
\text { Jumlah Skor } \\
\text { Rata-Rata Skor }\end{array}$ & $\begin{array}{c}2 \\
25 \\
2,5\end{array}$ & $\begin{array}{c}2 \\
26 \\
2,6\end{array}$ & $\begin{array}{c}2 \\
33 \\
3,3\end{array}$ \\
\hline & Kategori & Baik & Baik & $\begin{array}{l}\text { Sangat } \\
\text { Baik }\end{array}$ \\
\hline
\end{tabular}

Berdasarkan tabel 1, dapat diketahui bahwa keterampilan guru pada siklus I sampai dengan siklus III selalu mengalami peningkatan.

Hasil tersebut sejalan dengan hasil penelitian oleh Edriani Umar (2019) yang menjelaskan bahwa Pada pertemuan satu siklus I aktivitas guru memiliki skor penilaian sebesar 17 dengan persentase 60.7\% kategori cukup. Pada pertemuan kedua aktivitas guru dalam proses pembelajaran mengalami peningkatan, hal ini terbukti dengan meningkatnya jumlah skor penilaian menjadi 20 dengan persentase sebesar $71.4 \%$. Pada siklus II, pertemuan pertama aktivitas guru 
mengalami peningkatan skor penilaian menjadi 23 dengan persentase sebesar $82.1 \%$ dengan kategori baik, Pada pertemuan kedua skor penilaian aktivitas guru kembali mengalami peningkatan menjadi 26 dengan persentase sebesar $92.8 \%$ dengan kategori amat baik, Indikator yang terdapat dalam lembar pengamatan keterampilan guru telah disesuaikan dengan langkah-langkah pembelajaran dengan model picture and picture yang dipadukan dengan keterampilan dasar mengajar yang harus dimiliki guru yang meliputi keterampilan membuka pelajaran, keterampilan bertanya, keterampilan memberi penguatan, keterampilan mengadakan variasi, keterampilan menjelaskan, keterampilan membimbing diskusi kelompok kecil, keterampilan mengelola kelas, keterampilan pembelajaran perseorangan, dan keterampilan menutup pelajaran. (Rusman, 2012).

2. Aktivitas Siswa

Peningkatan Aktivitas siswa dalam pembelajaran IPS dapat dilihat pada tabel berikut :

Tabel 2. Peningkatan Aktivitas Siswa

\begin{tabular}{|c|c|c|c|c|}
\hline \multirow{2}{*}{ No. } & \multirow{2}{*}{ Indikator } & \multicolumn{3}{|c|}{$\begin{array}{c}\text { Rata-Rata Perolehan } \\
\text { Skor }\end{array}$} \\
\hline & & $\underset{\text { Siklus }}{\text { Sil }}$ & $\begin{array}{c}\text { Siklus } \\
\text { II }\end{array}$ & $\begin{array}{l}\text { Siklus } \\
\text { III }\end{array}$ \\
\hline 1 & $\begin{array}{l}\text { Kesiapan mengikuti pembelajaran IPS KD } 2.1 \\
\text { Mengenal jenis-jenis pekerjaan }\end{array}$ & 2,73 & 2,95 & 3,13 \\
\hline 2 & $\begin{array}{l}\text { Menanggapi penyampaian materi pembelajaran } \\
\text { IPS KD 2.1 Mengenal jenis-jenis pekerjaan }\end{array}$ & 2,26 & 2,43 & 2,86 \\
\hline 3 & $\begin{array}{l}\text { Memperhatikan gambar-gambar yang ditunjukkan } \\
\text { guru melalui media }\end{array}$ & 2,17 & 2,47 & 2,91 \\
\hline 4 & $\begin{array}{l}\text { Menjaga kekondusifan selama pembagian } \\
\text { kelompok }\end{array}$ & 1,69 & 2,69 & 3,17 \\
\hline 5 & Berpartisipasi dalam diskusi kelompok & 1,86 & 2,34 & 2,69 \\
\hline 6 & Menyusun laporan kelompok & 2,39 & 2,34 & 2,82 \\
\hline 7 & Melakukan presentasi kelompok & 0,91 & 1,91 & 2,17 \\
\hline 8 & $\begin{array}{l}\text { Mengajukan pertanyaan tentang konsep yang } \\
\text { belum jelas }\end{array}$ & 0,39 & 1,78 & 2,21 \\
\hline 9 & Berpartisipasi dalam menyimpulkan pembelajaran & 1,82 & 2,21 & 2,56 \\
\hline 10 & $\begin{array}{c}\text { Mengerjakan soal evaluasi } \\
\text { Jumlah Rata-rata skor } \\
\text { Kategori }\end{array}$ & $\begin{array}{l}3,08 \\
19,35 \\
\text { Cukup }\end{array}$ & $\begin{array}{c}3,08 \\
24,23 \\
\text { Baik }\end{array}$ & $\begin{array}{c}3,69 \\
28,26 \\
\text { Baik }\end{array}$ \\
\hline
\end{tabular}

Berdasarkan tabel 2 tentang peningkatan aktivitas siswa, terlihat bahwa aktivitas siswa mulai dari siklus I sampai dengan siklus III selalu mengalami peningkatan. Hal tersebut disebabkan karena ada upaya dari guru untuk selalu meningkatkan aktivitas siswa dalam pembelajaran untuk mewujudkan pembelajaran yang aktif, kreatif, dan menyenangkan melalui penerapan model picture and picture dengan media audio visual. Indikator pengamatan aktivitas siswa telah disesuaikan dengan berbagai macam aktivitas siswa menurut Dierich (dalam Hamalik, 2001) yaitu aktivitas visual (visual activities), aktivitas lisan (oral activities), aktivitas mendengarkan (listening activities), aktivitas menulis (writing activities), aktivitas menggambar(drawing activities), aktivitas motorik (motor activities), aktivitas mental (mental activities), dan aktivitas emosional (emotional activities).

Peningkatan aktivitas dalam pembelajaran dengan menerapkan model picture and picture juga dibuktikan oleh penelitian Hasniwati (2019) yang menyatakan bahwa hasil persentase aktivitas siswa pada siklus I sebesar 53.57 dengan kategori kurang. 
Pada pertemuan kedua sudah berjalan dengan baik dibuktikan oleh persentase perolehan aktivitas siswa sebesar 64.28 dengan kategori cukup. Pertemuan ketiga aktivitas siswa sudah berjalan dengan baik, hal ini dibuktikan oleh hasil observasi siswa yang meningkat menjadi 82.14 dengan kategori sangat baik.

3. Hasil Belajar Siswa

Berdasarkan hasil evaluasi siswa dalam penelitian siklus I mata pelajaran IPS melalui penerapan model Picture and Picture dengan media audio visual diperoleh data hasil belajar kognitif siswa sebagai berikut :

\begin{tabular}{|c|c|c|c|c|}
\hline No & Interval & Frekuensi & Persentase & Keterangan \\
\hline 1 & $57-61$ & 2 & $9 \%$ & Tidak Tuntas \\
\hline 2 & $62-66$ & 1 & $4 \%$ & Tidak Tuntas \\
\hline 3 & $67-71$ & 6 & $26 \%$ & Tidak Tuntas \\
\hline 4 & $72-76$ & 0 & $0 \%$ & - \\
\hline 5 & $77-81$ & 8 & $35 \%$ & Tuntas \\
\hline 6 & $\begin{array}{c}82-86 \\
\text { Jumlah }\end{array}$ & 6 & $\begin{array}{l}26 \% \\
100 \%\end{array}$ & Tuntas \\
\hline
\end{tabular}

Berdasarkan tabel di atas, hasil belajar kognitif siswa pada siklus I menunjukkan bahwa melalui penerapan model Picture and Picture dengan media audio visual, diperoleh hasil sebanyak 14 siswa (61\%) dinyatakan mencapai ketuntasan belajar dan 9 siswa (39\%) dinyatakan tidak tuntas dalam belajar. Rata-rata nilai klasikal siswa adalah 76 dengan nilai tertinggi 86 dan nilai terendah 57. Nilai yang sering muncul adalah antara $77-81$.

Hasil belajar siswa pada siklus II sebagai berikut :

Tabel 3. Tabel Distribusi Frekuensi Hasil Belajar Kognitif Siklus II

\begin{tabular}{ccccc}
\hline No & Interval & Frekuensi & Persentase & Keterangan \\
\hline 1 & $64-68$ & 2 & $9 \%$ & Tidak Tuntas \\
2 & $69-73$ & 3 & $13 \%$ & Tidak Tuntas \\
3 & $74-78$ & 0 & - & - \\
4 & $79-83$ & 8 & $35 \%$ & Tuntas \\
5 & $84-88$ & 6 & $26 \%$ & Tuntas \\
6 & $89-93$ & 4 & $17 \%$ & Tuntas \\
Jumlah & & & $\mathbf{1 0 0} \%$ & \\
\hline
\end{tabular}

Dalam pelaksanaan siklus II diperoleh hasil sebanyak 18 siswa (78 \%) dinyatakan mencapai ketuntasan belajar dan 5 siswa (22\%) dinyatakan tidak tuntas dalam belajar. Rata-rata nilai klasikal siswa adalah 81,2 dengan nilai tertinggi 93 dan nilai terendah 64 . Nilai yang sering muncul adalah antara $79-83$.

Hasil belajar siklus III adalah sebagai berikut:

Tabel 4. Tabel Distribusi Frekuensi Hasil Belajar Siklus III

\begin{tabular}{ccccc}
\hline No & Interval & Frekuensi & Persentase & Keterangan \\
\hline 1 & $71-75$ & 3 & $13 \%$ & Tidak Tuntas \\
2 & $76-80$ & 8 & $35 \%$ & Tuntas \\
3 & $81-85$ & 2 & $9 \%$ & Tuntas \\
4 & $86-90$ & 3 & $13 \%$ & Tuntas \\
5 & $91-95$ & 5 & $21 \%$ & Tuntas \\
6 & $96-100$ & 2 & $9 \%$ & Tuntas \\
Jumlah & & & $\mathbf{1 0 0} \%$ & \\
\hline
\end{tabular}


Berdasarkan tabel tersebut, dapat diketahui bahwa pada siklus III diperoleh hasil sebanyak 20 siswa (87\%) dinyatakan mencapai ketuntasan belajar dan 3 siswa $(13 \%)$ dinyatakan tidak tuntas dalam belajar. Rata-rata nilai klasikal siswa adalah 84,13 dengan nilai tertinggi 100 dan nilai terendah 76 . Nilai yang sering muncul adalah antara $79-80$.

Hasil belajar yang diperoleh dari ke-3 siklus tersebut menunjukkan adanya peningkatan kemampuan kognitif siswa dalam pelajaran IPS dengan menerapkan model picture and pictutre dan menggunakan media audio visual. Keberhasilan penggunaan media audiovisual untuk meningkatkan hasil kognitif siswa juga dibuktikan dengan adanya penelitian yang dilakukan oleh Ahmad Fujianto (2016) dengan perolehan hasil belajar siswa pada pelaksanaan tindakan siklus I dengan persentase $53 \%$. Perolehan pada siklus I ini belum mencapai target yang diharapkan yaitu $85 \%$. Persentase perolehan hasil belajar siswa pada siklus II hanya 20 siswa yang nilainya di atas kriteria ketuntasan minimum dengan persentase sebesar $66,66 \%$ siswa yang lulus KKM. Persentase kenaikan hasil belajar siklus I dengan hasil belajar siklus II adalah 13\% sebanyak 4 siswa. Peningkatan persentase hasil belajar siswa siklus II sampai dengan hasil belajar siswa siklus III sebesar 23,34\% sebanyak 7 siswa.

Hasil belajar afektif siswa dalam penelitian ini meliputii 4 indikator yang diamati, yaitu bertanggung jawab, percaya diri, bersikap santun, dan jujur. Skor yang diperoleh pada keseluruhan siklus mengalami peningkatan. Pada siklus I rata-rata nilai afektif siswa adalah 8,82 dengan persentase ketuntasan sebesar $55,16 \%$. Kemudian pada siklus II meningkat ditunjukkan oleh nilai rata-rata afektif siswa menjadi 10,30 dengan persentase $67,39 \%$. Dan pada siklus III mengalami peningkatan kembali ditunjukkan dengan nilai rata-rata afektif siswa menjadi 12,91 dengan persentase ketuntasan sebesar $80.70 \%$.

Hasil belajar psikomotorik siswa meliputi 3 indikator pengamatan yaitu persepsi, kesiapan, dan gerakan terbimbing. Hasil belajar psikomotor menunjukkan adanya peningkatan. Perolehan rata-rata nilai psikomotor siswa siklus I adalah 7,47 dengan persentase ketuntasan sebesar 62,31\%. Kemudian pada siklus II meningkat ditunjukkan oleh nilai rata-rata psikomotorik siswa menjadi 8,56 dengan persentase $71,37 \%$. Dan pada siklus III mengalami peningkatan kembali ditunjukkan dengan nilai rata-rata psikomotorik siswa menjadi 9,82 dengan persentase ketuntasan sebesar $81,88 \%$.

Hasil penelitian tersebut membuktikan adanya temuan baru dalam pembelajaran IPS yaitu penerapan model picture and picture dengan media audio visual adalah sebagai acuan untuk memperbaiki, meningkatkan, dan mengembangkan kualitas pembelajaran IPS. Oleh karena itu, seharusnya kualitas pembelajaran IPS diperbaiki dengan menerapkan model pembelajaran yang inovatif salah satunya adalah model picture and picture serta memanfaatkan media yang bervariasi seperti media audio visual. Penerapan model picture and picture dengan media audio visual juga mampu menciptakan kondisi pembelajaran yang aktif, menyenangkan, dan bermakna.

\section{SIMPULAN}

Berdasarkan hasil penelitian, dapat disimpulkan bahwa penerapan model picture and picture dengan media audio visual dapat meningkatakn keterampilan guru, aktivitas siswa dan hasil belajar siswa pada pembelajaran IPS SD kelas III. Penelitian ini dapat menambah referensi guru untuk menerapkan model picture and picture dengan media audio visual dalam pelaksanaan pembelajaran IPS, dengan harapan untuk menumbuhkan kreativitas guru dalam menciptakan pembelajaran yang inovatif, menarik, dan bermakna melalui serangkaian permainan. Oleh karena itu, guru 
sebaiknya menerapkan model picture and picture dengan media audio visual dalam pembelajaran, khususnya pada pembelajaran IPS.

Selain itu, penerapan model picture and picture dengan media audio visual juga berdampak pada siswa, yaitu memberikan variasi dan pengalaman gaya belajar yang berbeda dari biasanya yang berupa pembelajaran konvensional, menjadi pembelajaran yang aktif dan menyenangkan. Melaui penerapan model picture and picture dengan media audio visual, siswa diberi kesempatan untuk mengembangkan kemampuan dan kreativitasnya melalui kegiatan-kegiatan pembelajaran yang bermakna.

Melihat adanya pengaruh positif penerapan model picture and picture dengan media audio visual bagi pembelajaran khususnya IPS, maka sudah selayaknya guru mulai mengaplikasikan model pembelajaran inovatif seperti picture and picture dan memanfaatkan media yang bervariasi, salah satunya adalah media audio visual dalam pembelajaran di sekolah dengan sebaik-baiknya.

\section{DAFTAR PUSTAKA}

Arikunto,Suharsimi.2009.Penelitian Tindakan Kelas.Jakarta: Pt Bumi Aksara.

Daryanto. 2010. Media Pembelajaran.Yogyakarta: Gava Media.

Fujianto,A.,Jayadinata,Ak.,\& Kurnia,D. (2016). Penggunaan Media Audiovisual Untuk Meningkatkan Hasil Belajar Siswa Pada Materi Hubungan Antar Makhluk Hidup. Jurnal Pena Ilmiah,1(1). Diakses Dari Https://Ejournal.Upi.Edu/Index.Php/Penailmiah/Article/Viewfile/3576/Pdf

Hamdani. 2011. Strategi Belajar Mengajar. Bandung: Pustaka Setia.

Hasniwati. (2019). Penerapan Model Pembelajaran Picture And Picture Untuk Meningkatkan Hasil Belajar Ipa Siswa Kelas lia Sd Negeri 004 Cendirejo Kecamatan Pasir Penyu Kabupaten Indragiri Hulu. Jurnal Pajar (Pendidik Dan Pengajar), 3 (1), 189-197. Diakses Dari Https://Www.Researchgate.Net/Publication/331069137_Penerapan_Model_Pem belajaran_Pictue_And_Picture_Untuk_Meningkatkan_Hasil_Belajar_Ipa_Siswa_ Kelas_lia_Sd_Negeri_004_Cendirejo_Kecamatan_Pasir_Penyu_Kabupaten_Indr agiri_Hulu

Republik Indonesia. (2003). Undang-Undang Ri Nomor 20, Tahun 2003, Tentang Sistem Pendidikan Nasional.

Republik Indonesia. (1945). Undang-Undang Dasar Pasal 31, Tentang Kebebasan Setiap Warga Negara Indonesia Untuk Memperoleh Pendidikan.

Rusman. 2011. Model-Model Pembelajaran. Jakarta: Rajawali Pers.

Sapriya. 2012. Pendidikan Ips Konsep Dan Pembelajaran. Bandung : Pt. Remaja Rosdakarya.

Umar, Edriani.(2019). Penerapan Model Pembelajaran Picture And Picture Untuk Meningkatan Hasil Belajar Ipa Siswa Kelas li Sd Negeri 37 Mandau. Jurnal Pajar (Pendidik Dan Pengajar), 3 (5), 1036-1037. Diakses Dari Https:/Www.Researchgate.Net/Publication/335775594_Penerapan_Model_Pem belajaran_Picture_And_Picture_Untuk_Meningkatkan_Hasil_Belajar_Ipa_Siswa_ Kelas_li_Sd_Negeri_37_Mandau 